\title{
Algılanan İş Güvencesizliğinin Yaşam Doyumu Üzerindeki Etkisinde İşten Ayrılma Niyetinin Aracılık Rolü (The Mediating Role of Turnover Intention on the Effect of Perceived Job Insecurity on Life Satisfaction)
}

\section{Kemaleddin ERYEŞIL (iD) a}

a Şırnak Üniversitesi, İktisadi ve İdari Bilimler Fakültesi, İşletme Bölümü, Şırnak, Türkiye. k.eryesil@sirnak.edu.tr

\begin{tabular}{|c|c|}
\hline MAKALE $\mathrm{B}$ & ZET \\
\hline $\begin{array}{l}\text { Anahtar Kelimeler: } \\
\text { Algilanan İs }\end{array}$ & $\begin{array}{l}\text { Amaç - Bu çalışmanın amacı, kamu çalışanlarının algılanan iş güvencesizliğinin yaşam doyumu üzerindeki } \\
\text { etkisinde işten ayrılma niyetinin aracılık rolünü analiz etmektir. }\end{array}$ \\
\hline $\begin{array}{l}\text { Güvencesizliği } \\
\text { Yaşam Doyumu } \\
\text { İşten Ayrılma Niyeti }\end{array}$ & $\begin{array}{l}\text { Yöntem - Bu çalışmada algılanan iş güvencesizliğinin yaşam doyumu üzerindeki etkisinde işten ayrılma } \\
\text { niyetinin etkisi olup olmadığını belirlemek için nicel araştırma yöntemlerinden ilişkisel tarama modeli } \\
\text { kullanılmış̧ır. Bu amaç doğrultusunda Konya ilinde kamu kurumlarında çalışan } 425 \text { kişiden basit tesadüfî } \\
\text { örneklem aracılığıyla anket yöntemiyle veriler elde edilmiştir. Araştırmadaki veriler } 2019 \text { yılı Ekim-Aralık } \\
\text { ayları arasında toplanmıştır. Araştırma kapsamında çalışanların algılanan iş güvencesizliği düzeylerinin }\end{array}$ \\
\hline Gönderilme Tarihi 17 & elirlenmesinde De Cuyper ve arkadaşları (2010) tarafından geliştirilen ve Seçer (2011)'in çalışmasında \\
\hline Aralık 2020 & dllandığı algılanan iş güvencesizliği ölçeği, işten ayrılma niyetlerinin belirlenmesinde Mobley (1977) \\
\hline $\begin{array}{l}\text { Revizyon Tarihi } 1 \text { Mart } \\
2021\end{array}$ & $\begin{array}{l}\text { geliştirdiği ölçek ve yaşam doyumunun belirlenmesinde ise Diener ve arkadaşlarının (1985) geliştirdiği } \\
\text { ayrıca Köker (1991)'in Türkçeye uyarladığ ölçek kullanılmıştır. Araştırma değişkenlerine güvenirlilik } \\
\text { analizi yapılmış, ardından aralarındaki ilişkiyi incelemek için korelasyon ve çoklu regresyon analizleri }\end{array}$ \\
\hline Kabul Tarihi 15 Mart 2021 & yapılarak araştırmanın hipotezleri test edilmiştir. \\
\hline Araştırma Makalesi & $\begin{array}{l}\text { Bulgular - Araştırma bulgularına göre, kamu çalışanlarının algılanan iş güvencesizliğinin işten ayrılma } \\
\text { niyetlerini pozitif yönde etkilediği yaşam doyumunu da negatif yönde etkilediği bulunmuştur. Benzer } \\
\text { şekilde kamu çalışanlarının işten ayrılma niyetlerinin yaşam doyumunu ve algılanan iş güvencesizliğinin } \\
\text { ise yaşam doyumunu negatif yönde etkilediği bulunmuştur. Ayrıca, algılanan iş güvencesizliğinin yaşam } \\
\text { doyumu üzerindeki etkisinde işten ayrılma niyetinin aracılık rolü oynadığı görülmüştür. }\end{array}$ \\
\hline & $\begin{array}{l}\text { Tartışma - Bu sonuçlar dikkate alındığında bu çalışmada algılanan iş güvencesizliği, yaşam doyumu ve } \\
\text { işten ayrılma niyeti değişkenlerinin bir arada ele alınması ve örgütsel davranış yazınında bu değişkenleri } \\
\text { bir arada ele alan çalışmaya rastlanılmamış olması çalışmanın kalitesini artırmaktadır. Gelecekte özellikle } \\
\text { bu değişkenlerin farklı değişkenlerle ve özel sektör çalışanlarıyla araştırma konusu olarak ele alınması } \\
\text { önerilmektedir. }\end{array}$ \\
\hline
\end{tabular}

\section{ARTICLE INFO}

\section{Keywords:}

Perceived Job Insecurity

Life Satisfaction

Turnover Intention

Received 17 December 2020

Revised 1 March 2021

Accepted 15 March 2021

Article Classification:

Research Article

\section{ABSTRACT}

Purpose - The purpose of this study is to analyse the mediating role of turnover intention on the effect of civil servants' perceived job security on life satisfaction.

Design/methodology/approach - In this study, the correlational survey model, one of the quantitative research methods, was used in order to determine whether perceived job insecurity has an effect on life satisfaction or not. For this purpose, data was collected from 425 people working in public institutions in Konya province through simple random sampling using questionnaire method. Data of the study were collected between the months of October and December in 2019. Perceived job security scale developed by De Cuyper and colleagues (2010) and used by Seçer (2011) was used in order to measure perceived job security. The scale developed by Mobley (1977) was used for the purpose of identifying turnover intention. The scale developed by Diener and colleagues (1985) and adapted to Turkish by Köker (1991) was used in order to measure life satisfaction. Reliability analysis was performed on the research variables, then the hypotheses of the research was tested by performing correlation and multiple regression analyzes to examine the relationship between them.

Findings - Research findings suggest that civil servants' perceived job insecurity has a positive impact on turnover intention and a negative impact on life satisfaction. Similarly, it was found out that civil servants' turnover intention and perceived job insecurity have a negative effect on life satisfaction. Moreover, it was observed that turnover intention has a mediating role on the effect of perceived job insecurity on life satisfaction.

Discussion - Taking these results into account, this study discusses the variables of perceived job insecurity, life satisfaction and turnover intention altogether. It was seen that there is no other study that covers these variables at the same time, which increases the quality of this study. In the future, it is recommended that these variables be addressed with different variables and private sector employees as a research topic.

\section{Önerilen Atıf/ Suggested Citation}

Eryeşil, K. (2021). Algılanan İş Güvencesizliğinin Yaşam Doyumu Üzerindeki Etkisinde İşten Ayrılma Niyetinin Aracilık Rolü, İşletme Araştırmaları Dergisi, 13 (1), 639-650. 


\section{GİRIŞ}

1970'lerin sonlarından bu yana ekonomideki dalgalanmalar, endüstriyel yeniden yapılanma, teknolojik değişiklikler ve küreselleşmenin etkisiyle oluşan amansız rekabet ortamı (Buitendach ve Witte, 2005: 28), küresel sosyo-politik gelişmeler, bilgi ve iletişim teknolojisindeki gelişmeler çalışma hayatının seyrini önemli derecede değiştirmiş, finansal tasarruflar, birleşme ve satın almalar (Hassard vd., 2013), küçülmeler, öngörülemeyen ekonomik durum, daha sert rekabet standartları ve diğer yapısal değişim türleriyle sonuçlanmıştır. Birçok çalışan için çalışma hayatındaki bu değişiklikler işlerinin niteliği ve gelecekteki varlığ1 konusunda güvensizlik duygularına neden olabilmektedir. Bu durum çalışanlar arasında yalnızca işleriyle ilgili değil, aynı zamanda genel olarak gelecekle ilgili de artan güvensizlik duyguları hissetme eğilimi oluşturmaktadır (Sverke vd., 2002: 242).

İş güvencesizliği kavramı sosyal bir fenomendir, yani istihdam ve işsizlikle ilgili öznel bir algı olarak deneyimlenmekte ve bir bireyin işinin istikrarlı kalacağına dair güvencelerden yoksun olduğunda ortaya çıkan güvensizliği, belirsizliği, güçsüzlüğü ve çaresizliği yansıtmaktadır. İş güvencesizliğinin, işsizliğe yol açan sürecin en stresli yönü olduğu ve çalışanlar üzerinde işsizliğin kendisinden daha kötü bir etkiye sahip olduğu belirtilmektedir (Nella vd., 2015: 1). Yaşam doyumu, kişinin yalnızca mevcut mutluluk düzeyinin değil, bir bütün olarak yaşamının değerlendirilmesidir (Ackerman, 2019). Yapılan çalışmalarda, iş güvencesizliği yaşayan çalışanların yaşam doyumunun daha düşük olduğunu göstermektedir (Lim, 1997; De Witte 2005). Çalışanların işten ayrılma niyeti, bir bireyin kuruluşundan belirli bir süre içinde ayrılma niyeti olarak tanımlanmaktadır. Ayrılma niyeti, bireylerin işlerine ve iş yerlerine yönelik olumsuz görüş ve tutumlarından kaynaklanmaktadır (Behery vd., 2016: 187).

İş güvencesizliği, çalışanların refahı ve iş performansı üzerinde olumsuz etkilere neden olan korku, potansiyel kayıp ve kaygıyı içeren önemli bir iş stresi kaynağı olarak görülmektedir (Ngo vd., 2013: 58). Bir stres faktörü olarak iş güvencesizliği, geri çekilme davranışını arttırmakta; daha yüksek düzeyde devamsızlık ve işten ayrılma niyeti ile sonuçlanmaktadır. Bir kişi mevcut işini sürdürme konusunda daha belirsiz hale geldikçe alternatif, daha güvenli iş fırsatları arama eğiliminde olacaktır (Ismail, 2015: 313). Sonuç olarak iş güvencesizliği arttıkça iş arama davranışını artacak ve dolayısıyla işten ayrılma niyeti de artacaktır (Ashford vd., 1989; Tivendell ve Bourbonnai, 2000; Clark, 2005; Ismail, 2015). İşten ayrılma niyeti artan çalışanın da dolayısıyla yaşam doyumu olumsuz anlamda etkilenecektir.

Bu çalışma, kamu çalışanlarının algılanan iş güvencesizliğinin yaşam doyumu üzerindeki etkisinde işten ayrılma niyetinin aracılık rolünü incelemeyi amaçlamaktadır. Bu kapsamda, Konya ilinde kamu kurumlarında çalışan 425 kişiden elde edilen veriler istatistiksel teknikler ile analiz edilecek her üç kavram arasındaki ilişkiler ortaya konulmaya çalışılacaktır.

\section{TEORİK ÇERÇEVE}

\subsection{Algılanan İş Güvencesizliği}

İş güvencesizliğinin sadece işgücü piyasası üzerinde etkileri olmakla kalmayıp, aynı zamanda çalışanların refahını ve tutumlarını da tehlikeye attığından, yönetim bilimleri, psikoloji veya iş sağlığı dahil olmak üzere farklı disiplinler konuya ilgi göstermiş ve önemli miktarda araştırma yapılmıştır. Doğal olarak, iş güvencesizliğinin daha fazla karmaşık tanımları ortaya çıkmıştı. Bazı yazarlar için, istihdam kaybı riskinin öznel bir algısı iken, bazıları için ise güvensizlik yapısı biraz daha karmaşık ve bir iş kaybının ötesine geçen diğer çalışma alanlarını tehlikeye atmaktadır. İş güvencesizliği, mevcut işin kaybedilmesi durumunda yeni bir iş bulma, ücretler, programlar, görevler vb. gibi temel iş koşullarının kötüleşmesi, kariyer ve profesyonel gelişimin azaltılması veya üstlerin desteği ve etkisi gibi psiko-sosyal özellikler içermektedir (Salas-Nicas vd., 2020: 1).

İş güvencesizliği veya "işsizlik tehdidi" kavramı literatürde farklı araştırmacılar tarafından çeşitli şekillerde tanımlanmıştır. İş güvencesizliği kavramını Greenhalgh ve Rosenblatt (1984), "tehdit altındaki bir iş durumunda istenen sürekliliği korumak için algılanan güçsüzlük", Van Vuuren ve Klandermans (1990), "işin gelecekteki kalıcılığı hakkında endişeler", Heany vd. (1994), "mevcut işin devamlılı̆̆ına yönelik potansiyel bir tehdit algisı", Davy vd. (1997), "bir iş durumunda süreklilik beklentileri", Sverke vd. (2002), "iş kaybıyla ilgili temel ve istemsiz bir olayın öznel olarak deneyimlenmiş beklentisi", De Witte (2005), "algılanan iş kaybı tehdidi ve bu tehditle ilgili endişeler", Landsbergis vd. (2014), "iş düzeyinde, istihdam koşulları ve iş 
organizasyonunun neden olduğu ve bir işçinin kaybetme korkusu veya iş istikrarsızlı̆̆ı algısını yansıtan bir psiko-sosyal stres unsuru", Mathebulaa (2015) ise, "çalıştığınız şirket veya kuruluş içindeki çeşitli nedenlerden dolayı mevcut potansiyel işinizi kaybetme korkusu" olarak tanımlamaktadır.

Van Vuuren (1990), iş güvencesizliğini, bireyin çalıştığı kurumda devam etmesine yönelik hissettiği endişe şeklinde tanımlamakta ve iş güvencesizliğinin merkezinde üç bileşeninin yer aldığını vurgulamaktadır. İlk bileşen, öznel bir deneyim veya algıya işaret etmekte; ikinci bileşen, gelecekle ilgili belirsizlik ve üçüncü bileşen ise işin bu şekilde devamına ilişkin şüpheleri içermektedir (Buitendach ve De Witte, 2005: 28). Her şeyden önce, öznel bir deneyim veya algı olan iş güvencesizliğinde, aynı durum farklı çalışanlar tarafından farklı algılanabilmektedir. Bazıları nesnel bir neden olmadığında kendilerini güvensiz hissederken, bazıları ise işleri gerçekte tehdit edildiğinde kendilerini güvende hissedebilmektedirler. İş güvencesizliği aynı zamanda geleceğe dair belirsizlik anlamına da gelir: ilgili kişi için çalışmaya devam edip edemeyeceği veya işten çıkarılıp çıkarılamayacağı belirsizdir. Bu durumda gelecek belirsizdir, kişi işten çıkarılmaya ve gelecekteki (işsiz) işe hazırlanmaya başlayabilir. Son olarak, iş güvencesizliği için işin devamına ilişkin şüpheler çok önemlidir (De Wıtte, 1999: 156). Çok boyutlu bir bakış açısına göre iş güvencesizliği kavramı yalnızca çalışanların iş sürekliliği hakkında hissettikleri belirsizlik miktarını değil, aynı zamanda terfi fırsatları ve örgütsel faydalar gibi işin belirli boyutlarının kalıcılığını da ifade etmektedir (Buitendach ve Witte, 2005: 28).

Örgütsel davranış araştırmacılarının çoğunluğu küresel bir bakış açısını benimsemiş ve iş güvencesizliğini sübjektif olarak algılanan ve istenmeyen bir şekilde gelecekte mevcut işi kaybetme olasılığı ile iş kaybı olasılı̆̆ına ilişkin korku veya endişeler olarak tanımlamıştır (De Witte, 1999). Bu bağlamda, iş güvencesizliğinin sübjektif olarak algılanan istemsiz iş kaybı olasılığını ifade ettiğini vurgulamak da önemlidir. Kişinin işini kaybetme bilişsel olasılığına (işten çıarılacağımı düşünüyorum) ve bunun duygusal deneyimine (işsiz kalacağımdan endişeliyim) atıfta bulunarak bilişsel ve duygusal iş güvencesizliği arasında ayrım yapılmaktadır (Nella vd., 2015: 1). İş güvencesizliğini ayırt etmenin bir başka yolu da iş güvencesizliği içinde çalışmaya devam edip etmeyecekleri yani iş kaybıyla ilgili endişeyi ifade eden niceliksel iş güvencesizliği ile çalışma koşullarının bozulması, kariyer fırsatlarının olmaması, maaş, sağlık sigortası ve sosyal hayatı kaybetme endişesi gibi işin önemli yönlerini ifade eden niteliksel iş güvencesizliği arasında ayrım yapmaktır (De Witte, 2005: 2; Gürbüz ve Dede, 2018: 75).

Çalışanların iş güvencesizliği algısına tepkisi psikolojik sözleşme teorisi ile açıklanmaktadır. Bu nedenle, algılanan iş güvencesizliği ile ilişkili olumsuz sonuçlar, psikolojik sözleşmenin ihlal edilmesinin bir sonucu olarak kavramsallaştırılmaktadır (Kekesi ve Agyemang, 2014: 20). Psikolojik sözleşme teorisine göre iş güvencesizliği, çalışanların işverenleriyle yaptıkları psikolojik sözleşmenin ihlalini temsil etmektedir. Çalışanlar, kuruluşlarının karşılıklı değişim yükümlülüklerini yerine getiremediklerini algıladıklarında (adil ödül ve sürekli istihdam karşılığında tatmin edici bir iş performansı vb.), daha düşük iş tatmini ve kuruluşlarına olan bağlılığı daha az olacaktır (Hang-Yue vd., 2013: 60). Ayrıca, psikolojik sözleşmenin ihlali çalışanlar arasında moral bozukluğu, çaresizlik, öfke, güvensizlik ve hayal kırıklı̆̆ı gibi bazı olumsuz duygusal tepkilere neden olabilmekte ve bu da iş motivasyonlarını zayıflatmaktadır (Ashford vd., 1989: 803).

Birey açısından iş güvencesizliği algısı, çalışanların refahı ve iş doyumu üzerinde zararlı etkilere sahip olabilirken; organizasyonun bakış açısından iş güvencesizliği, çalışanların organizasyona yönelik tutumları, organizasyonda kalma isteği ve performans üzerinde olumsuz sonuçlara yol açabilmektedir (Sverke vd., 2002: 242).

\subsection{Yaşam Doyumu}

Doyum bir ruh halidir. Bu terim hem "memnuniyet" hem de "zevk" anlamına gelmektedir. Bu nedenle zihinsel ve duygusal değerlendirmeleri kapsayan doyum zamanla azalan ve durağan olabilmektedir (Veenhoven, 1996: 15). Doyum, yeterince yapmak veya yapmak anlamına gelen Latince bir kelimedir. Kişinin yaşamından tatmin olması, kişinin yaşam koşullarından memnun olması, kabullenmesi veya kişinin bütün olarak yaşamı için kendi istek ve ihtiyaçlarının karşılanması anlamına gelmektedir (Sousa ve Lyubomirsky, 2001: 668).

Yaşam doyumu ise, çoklu yaşam alanlarının bireysel tercihlerine ve bu alanlardaki doyuma dayalı öznel olarak algılanan yaşam kalitesi (Goldbeck vd., 2007: 970), bireyin tüm yaşamının genel kalitesini pozitife çevirme derecesi veya bireyin yaşadığı hayattan zevk alma derecesi şeklinde ifade edilmektedir (Veenhoven, 
1996: 15). Yaşam doyumu, bireylerin psikolojik refahı ve yaşam kalitesi hakkındaki genel yargılarını da ifade etmektedir (Lam ve M. Zhou, 2020: 2). Yaşam doyumunun özü, kişinin yaşam kalitesinin öznel bir değerlendirmesidir. Doğası gereği bir değerlendirme olduğu için, yaşam doyumunun yargılarının büyük bir bilişsel bileşeni vardır (Sousa ve Lyubomirsky, 2001: 668).

Yaşam doyumu, genel olarak yaşamla ilgili küresel bir memnuniyet, tatmin veya mutluluk duygusu olarak tanımlanmaktadır. Yapılan araştırmalarda, yaşam doyumunun hem bireysel rollerden memnuniyet hem de genel sağlık ve refah (iyi oluş) ile ilişkili olduğu fikrini desteklemektedir (Perrone ve Civiletto, 2004: 107). Yaşam doyumu için mevcut eşanlamlı kavramlar ise "mutluluk ve öznel iyi oluş" kavramlarıdır. "Mutluluk" kelimesinden ziyade yaşam doyumu terimini kullanmanın bir avantajı, kavramın öznel karakterini vurgulamasıdır. Mutluluk kelimesi, özellikle filozoflar tarafından nesnel(objektif) bir iyiliğe atıfta bulunmak için de kullanılmaktadır. Yaşam doyumu anlayışı, öznel iyi oluşun geniş bir tanımıdır. Öznel iyi oluş, hayata karşı tutumun hem duygusal hem de bilişsel yönlerini birleştirmektedir. Ayrıca yaşam doyumu terimi, mevcut duygulardan veya spesifik psikosomatik semptomlardan ziyade yaşamın genel değerlendirmesini ifade ettiği için "öznel iyi oluş" kavramına göre daha avantajlı bir konuma sahiptir (Veenhoven, 1996: 15).

Yaşam doyumu, hayata karşı genel olarak olumlu ve yansıtıcı bir tutumdur. Duygunun eşlik ettiği geçmişin perspektifine atıfta bulunan öznel bir algılama ve değerlendirme sürecidir. Yaşam doyumu, bir yanda yaşam iradesi ve diğer yanda yaşam kalitesi kadar kalıcı olmasa da duyusal deneyimlerden daha istikrarlı bir yapıdır (Kasprzak, 2010: 144).

Yaşam doyumu, kişinin yaşam deneyiminin gerek fiziksel gerek de psikolojik yönden istek ve gereksinimlerini gidermesi şeklinde ifade edilmektedir. İstek ve gereksinimler hayatın birçok alanında, farklı şekillerde ve rollerde yer almaktadır. Çeşitli şekillerde genel yaşam doyumuna ciddi düzeyde tesirleri olduğu düşünülen iş, bireylerin gereksinimlerini ve isteklerini gidermelerine yardımcı olan gelir kaynağıdır. Buna ek olarak, işi insanların benlik kavramı ve benlik saygısı üzerinde önemli bir etkiye sahip olduğuna dair kanıtlar vardır. Bir kişinin işini kaybetmenin stresli etkileri, yani işsizlik de iyi belgelenmiştir. İş ve yaşam doyumu arasındaki bağlantı şüphesiz olduğundan, araştırmanın ana hedeflerinden biri, işyerindeki değişiklikler yoluyla yaşam doyumunu veya yaşam kalitesini iyileştirme sorunu hakkında yararlı düşünme yolları sağlayan teorik modeller oluşturmak olmuştur (Demerouti vd., 2000: 456).

\section{3. İşten Ayrılma Niyeti}

Çalışanların işten ayrılma niyeti, örgütsel davranış alanında yaygın olarak kullanılan bir kavramdır. Organizasyonlar çalışanlara işe alım, eğitim ve gelişim açısından yatırım yapmakta, onların organizasyon içinde devamını sağlamakta ve elde tutmaktadır (Appollis, 2010: 34). Bu nedenle, işten ayrılma niyetinin belirleyicileri işten ayrılmayı düşünen çalışan için olduğu kadar, çalışan sürekliliği, eksikliği, yeni personelin işe başlama ve eğitiminde yer alan yüksek maliyetler ve örgütsel verimlilik sorunuyla karşı karşıya kalan yönetici için büyük önem taşımaktadır (Van Schalkwyk vd., 2010: 3).

Bir işverenden ayrılma niyeti, kişinin istihdamıyla ilgili mevcut memnuniyetsizliğin göstergesi olarak düşünülmektedir. Genel anlamda "ayrılma niyeti", bir çalışanın mevcut organizasyonunu terk etme niyeti olarak ifade edilmektedir. Spesifik olarak ayrılma niyeti ise, bir bireyin yakın gelecekte bir organizasyondan ayrılma olasılığına ilişkin öznel tahminini ifade etmektedir.

Ayrılma niyeti, yakın gelecekte bir organizasyonu terk etmek için bilinçli ve kasıtlı bir arzu olarak kabul edilmekte ve geri çekilme biliş aşamasındaki dizinin nihai kısmı şeklinde düşünülmektedir. Öte yandan kalma niyeti ise çalışanların organizasyonda kalmak için bilinçli ve kasıtlı istekliliğini ifade etmektedir (Cho vd., 2009: 375).

Ayrılma niyeti, çalışanın mevcut işi bırakma maksadı ve yakın zamanda alternatif bir iş bulmaya devam etme planı olarak tanımlanmaktadır. Bir bireyin organizasyonlarından ayrılma niyeti birçok stres modeline dahil edilmiştir. Özellikle ayrılma niyeti, çalışanların iş alternatiflerine ilişkin değerlendirmelerini ve algılarını belirtmektedir (Rizwan vd., 2014: 4).

İşten ayrılma niyetini, Mobley vd. (1978), “bir çalışanın bir organizasyondan ayrılma olasılığı”, Muchinsky ve Morrow (1980), "bir bireyin bir organizasyondan gönüllü olarak işten çıkarılması", Price (1989), "mevcut 
çalışanların kuruluştan ayrılması", Vandenberg ve Nelson (1999), "bireyin yakın gelecekte bir noktada kalıcı olarak kurumdan ayrılma olasılığı" olarak tanımlamaktadır.

Boshoff vd. (2002), işten ayrılma niyetini, bir bireyin işvereninin yanında kalmak istemediğine dair görüşünün gücü olarak tanımlamaktadır. Ayrılma niyeti bağımlı bir değişken olarak görülmekte ve bir bireyin yakın gelecekte kurumdan ayrılma olasılığının bir göstergesi olarak kullanılmaktadır. Yapılan araştırmalarda, bırakma niyetinin bireylerin mevcut durumlarını değerlendirmeleriyle başladığını ve ardından kesin bir bırakma niyetine ulaşılıncaya kadar birkaç ileri aşamadan geçtiklerini varsaymaktadır (Appollis, 2010: 35).

İşten ayrılma niyeti genellikle iş güvencesizliğinin bir sonuç değişkeni olarak kullanılmıştır. İşten ayrılma niyeti, bir çalışanın kuruluşunu terk etme eğilimidir. Ashford vd. (1989)'ine göre, iş güvencesizliği ile işten ayrılma niyetleri arasındaki ilişkinin mantığında, bireylerin stresli durumlardan uzaklaşma eğiliminde olmaları yer almaktadır. Dolayısıyla, küçülme süreçlerine maruz kalma ve algılanan iş kaybı tehditleri ve önemli iş özelliklerinin kaybıyla ilgili güvensizlik, işten ayrılma niyetleri ile ilişkilendirilmiştir (Emberland ve Rundmo, 2010: 453). Nitekim iş güvencesizliğinin işten ayrılma niyetiyle pozitif bir ilişkisi olduğu gözlemlenmiştir (Rosenblatt vd., 1999; Chirumbolo ve Hellgren, 2003; Sora vd., 2010: 60). Bu durum, iş güvencesizliği algısına sahip bireylerin işten ayrılma niyetlerinin yüksek olmasının nedenini göstermektedir. Yapılan araştırmalarda, iş güvencesizliğinin bir sonucu olarak gönüllü işten ayrılma niyetine işaret etmekte ve tipik olarak işgücü piyasasında en çekici, en kalifiye aynı zamanda kuruluş için en değerli çalışanların işyerinden ayrılma eğiliminde ilk sırada olduğunu göstermektedir (Kozlowski vd., 1993; Pfeffer, 1998).

\section{YÖNTEM}

\subsection{Araştırmanın Modeli ve Hipotezleri}

$\mathrm{Bu}$ araştırmada nicel araştırma yöntemlerinden ilişkisel tarama modeli kullanılmıştır. Araştırmanın amacı doğrultusunda oluşturulan araştırma modeli aşağıdaki Şekil 1'te yer almaktadır.

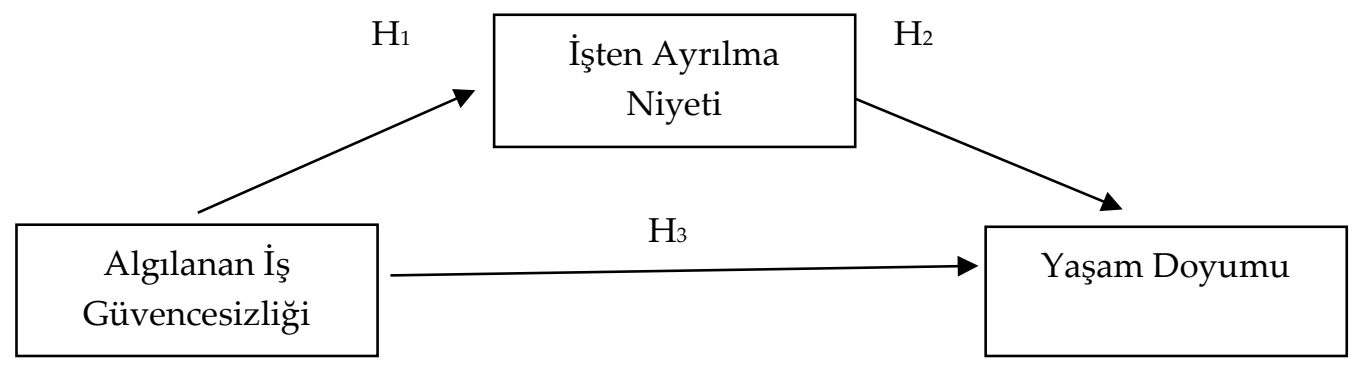

Şekil 1. Araştırma Modeli

Araştırma modeli kapsamında geliştirilen araştırma hipotezleri aşağıda belirtilmiş̧tir:

$\mathrm{H}_{1}$ : Algılanan iş güvencesizliği işten ayrılma niyetini pozitif yönde etkiler.

$\mathrm{H}_{2}$ : İsten ayrılma niyeti yaşam doyumunu negatif yönde etkiler

$\mathrm{H}_{3}$ : Algılanan iş güvencesizliği yaşam doyumunu negatif yönde etkiler.

$\mathrm{H}_{4}$ : Algılanan iş güvencesizliğinin yaşam doyumu üzerindeki etkisinde işten ayrılma niyetinin aracılık rolü vardir.

\subsection{Evren ve Örneklem}

$\mathrm{Bu}$ çalışmanın amacı algılanan iş güvencesizliğinin yaşam doyumu üzerindeki etkisinde işten ayrılma niyetinin aracılık rolünün incelenmesidir. Araştırmadaki veriler 2019 yılı Ekim-Aralık ayları arasında toplanmıştır. Araştırmanın evrenini Konya ilinde kamu kurumlarında çalışan personeller oluşturmaktadır. Araştırmanın yapıldığı zaman aralığında Konya ilinde çalışan personel sayısının yaklaşık olarak 78.000 olduğu tespit edilmiştir (www.konya.gov.tr). Elde edilen örneklemin evreni temsil etme gücü açısından +-0.05 örnekleme hatasında 384 kişilik bir örneklemin 100000 kişilik evreni temsil yeteneğine sahip olduğu belirtilmiştir (Coşkun vd., 2015). Bu kapsamda araştırmada Konya ilinde kamu kurumlarında çalışan 425 kişiden basit tesadüfî örneklem aracılığıyla anket yöntemiyle veriler elde edilmiştir. 


\subsection{Veri Toplama Aracı}

Bu çalışmada algılanan iş güvencesizliği algısının yaşam doyumu üzerindeki etkisinde işten ayrılma niyetinin etkisi olup olmadığını belirlemek için nicel araştırma yöntemi kullanılmıştır. Bu amaçla, 5 adedi demografik özellikleri görmeye yönelik, 14 adedi ölçek ifadeleri olmak üzere 22 maddeden oluşan anket formu hazırlanmıştır. Algılanan iş güvencesizliği ölçeği 4 ifade, yaşam doyumu ölçeği 5 ifade ve işten ayrılma niyeti ölçeği 5 ifade içermektedir. Çalışanların algılanan iş güvencesizliği düzeylerinin belirlenmesinde De Cuyper ve arkadaşları (2010) tarafından geliştirilen ve Seçer (2011)'in çalışmasında kullandığı algılanan iş güvencesizliği ölçeği, işten ayrılma niyetlerinin belirlenmesinde Mobley (1977) geliştirdiği ölçek ve yaşam doyumunun belirlenmesinde ise Diener ve arkadaşlarının (1985) geliştirdiği ayrıca Köker (1991)'in Türkçeye uyarladığı ölçek kullanılmıştır.

\subsection{Verilerin Analizi}

Anket formlarından elde edilen veriler SPSS (Statistical Package for Social Sciences) kullanılarak analiz edilmiştir. Araştırma değişkenlerine güvenirlilik analizi yapılmış, ardından aralarındaki ilişkiyi incelemek için korelasyon ve çoklu regresyon analizleri yapılarak araştırmanın hipotezleri test edilmiştir. Sonuçlar çalışmanın bulgular bölümünde verilmektedir.

\section{BULGULAR}

Tablo 1. Katılımcıların Demografik Özellikleri

\begin{tabular}{|c|c|c|c|c|c|}
\hline Demografik Özellikler & $\mathbf{n}$ & $\%$ & Demografik Özellikler & $\mathrm{n}$ & $\%$ \\
\hline \multicolumn{3}{|l|}{ Cinsiyet } & \multicolumn{3}{|l|}{ Yaș } \\
\hline Kadın & 252 & $\% 59,1$ & 18-30 yaş arası & 166 & $\% 39,1$ \\
\hline Erkek & 173 & $\% 40,9$ & $31-40$ yaş arası & 209 & $\% 49,2$ \\
\hline \multicolumn{3}{|l|}{ Medeni Durum } & $41-50$ yaş arası & 44 & $\% 10,4$ \\
\hline Evli & 272 & $\% 63,8$ & 51 yaş ve üzeri & 6 & $\% 1,4$ \\
\hline Bekar & 153 & $\% 36,2$ & \multicolumn{3}{|l|}{ Eğitim } \\
\hline \multicolumn{3}{|l|}{ Çalışma Süresi } & İlköğretim & 12 & $\% 2,9$ \\
\hline 1 yıldan az & 43 & $\% 10,1$ & Lise & 44 & $\% 10,1$ \\
\hline 1-5 yıl arası & 110 & $\% 26,1$ & Üniversite & 255 & $\% 60,9$ \\
\hline 5-10 yıl arası & 136 & $\% 31,9$ & Yüksek Lisans & 74 & $\% 17,4$ \\
\hline 10 yıl ve üzeri & 136 & $\% 31,9$ & Doktora & 40 & $\% 8,7$ \\
\hline Toplam & 425 & $\% 100$ & Toplam & 425 & $\% 100$ \\
\hline
\end{tabular}

Araştırmaya katılan çalışanların büyük bir kısmının evli (\%63,8), kadın (\%59,1), 18-40 yaş arası (\%88,3), üniversite mezunu $(\% 60,9)$ olduğu ve 5 yıldan uzun süredir $(\% 63,8)$ kamu kurumunda çalıştıkları tespit edilmiştir.

Tablo 2. Araştırma Değişkenlerinin Yapı Geçerliliği Analizi Sonuçları

\begin{tabular}{|l|c|c|c|}
\hline & $\begin{array}{c}\text { Algılanan İs } \\
\text { Güvencesizliği }\end{array}$ & $\begin{array}{c}\text { İşten Ayrılma } \\
\text { Niyeti }\end{array}$ & $\begin{array}{c}\text { Yaşam } \\
\text { Doyumu }\end{array}$ \\
\hline \multirow{3}{*}{ KMO ve Barlett Uygunluk Testi } & $\begin{array}{c}0.889 \\
\left(X^{2}=2194.416\right)\end{array}$ & $\begin{array}{c}0.783 \\
\left(X^{2}=424.894\right)\end{array}$ & $\begin{array}{c}0.821 \\
\left(X^{2}=1007.410\right)\end{array}$ \\
\cline { 2 - 4 } & $(\mathrm{p}<0,001)$ & $(\mathrm{p}<0,001)$ & $(\mathrm{p}<0,001)$ \\
\hline \multirow{2}{*}{$\begin{array}{l}\text { Faktör Yüklerine Göre Faktör Sayısı ve } \\
\text { Toplam Açıklanan Varyans }\end{array}$} & 4 İfade & 5 İfade & 5 İfade \\
\cline { 2 - 4 } & 1 Faktör & 1 Faktör & 1 Faktör \\
\cline { 2 - 4 } & 74.211 & 69.884 & 69.474 \\
\hline
\end{tabular}

Çalışmadaki ölçeklerin bütününe yapılan açıklayıcı faktör analizi sonucunda, Barlett küresellik testi sonucunun anlamlı $(\mathrm{p}<0.01)$ olduğu; Kaiser-Meyer-Olkin değerinin algılanan iş güvencesizliği ölçeğinin 0,889 , işten ayrılma niyeti ölçeğinin 0,783 ve yaşam doyumu ölçeği için 0,821 olduğu tespit edilmiştir. Açıklayıc1 faktör analizi kapsamında algılanan iş güvencesizliği ölçeğine ilişkin elde edilen yapının Seçer (2011) tarafından ileri sürülen yapı ile uyumlu olduğu ve ölçeğin tek boyutta ele alınabileceği tespit edilmiştir. İşten ayrılma niyeti ölçeğine ilişkin elde edilen yapının ise Mobley (1977) tarafından ileri sürülen yapı ile uyumlu 
olduğu ve benzer şekilde yaşam doyumu ölçeğine ilişkin yapılan faktör analizi sonucunda ölçeğin Köker (1991) tarafından ileri sürülen yapı ile uyumlu olduğu ve tek boyutta toplandığı ifade edilebilmektedir. Araştırmada kullanılan ölçeklerin ortalama, standart sapma, korelasyon ile güvenilirlik değerleri Tablo 3’de gösterilmiştir.

Tablo 3. Değişkenlere Ait Ortalama, Standart Sapma, Güvenilirlik ve Korelasyon Değerleri

\begin{tabular}{|l|l|l|l|l|l|}
\hline \multicolumn{1}{|c|}{ Değişkenler } & \multicolumn{1}{|c|}{$\boldsymbol{X}$} & \multicolumn{1}{|c|}{ SD } & \multicolumn{1}{|c|}{$\mathbf{1}$} & \multicolumn{1}{|c|}{$\mathbf{2}$} & \multicolumn{1}{|c|}{$\mathbf{3}$} \\
\hline Algılanan İş Güvencesizliği (1) & 2.22 & 0.70 & $(.918)$ & & \\
\hline İşten Ayrılma Niyeti (2) & 2.12 & 0.93 & $0.596^{* *}$ & $(.855)$ & \\
\hline Yaşam Doyumu (3) & 3.82 & 0.59 & $-0.429^{* *}$ & $-0.279^{* *}$ & $(.845)$ \\
\hline
\end{tabular}

Not: ${ }^{*} \mathrm{p}<.05,{ }^{* *} \mathrm{p}<.01$.

Araştırma değişkenlerine ait tanımlayıcı istatistikler değerlendirildiğinde, çalışanlarının iş güvencesizliği algiSı (Ort.=2.22; S.S.=0.70) ve işten ayrılma niyeti düzeylerinin (Ort.=2.12; S.S.=0.93) düşük düzeyde olduğu ve yaşam doyumu düzeylerinin (Ort.=3.82; S.S.=0.59) ise yüksek düzeyde olduğu sonucuna ulaşılmıştır. Ayrıca araştırma değişkenlerine ilişkin pearson korelasyon analizi sonuçları incelendiğinde, algılanan iş güvencesizliği ve işten ayrılma niyeti arasında orta düzeyde ve pozitif yönde ( $r=0.596, p<0.01)$, algılanan iş güvencesizliği ve yaşam doyumu arasında orta düzeyde $(\mathrm{r}=-0.429, \mathrm{p}<0.01)$ negatif yönde bir ilişkiden söz edilebilmektedir. Ayrıca işten ayrılma niyeti ve yaşam doyumu arasında düşük düzeyde $(r=-0.279, p<0,001)$ negatif yönde bir ilişkiden söz edilebilmektedir. Araştırma değişkenlerinin güvenilirlik analizi sonuçları değerlendirildiğinde ise, algılanan iş güvencesizliği Cronbach Alpha katsayısının 0.918, işten ayrılma niyeti Cronbach Alpha katsayısının 0.855) ve yaşam doyumu Cronbach Alpha katsayısının 0.845 olması ölçeklerin yüksek derecede $(0,60>\alpha>0,80)$ güvenilir olduğunu göstermektedir. Araştırma hipotezlerinin test edilmesi ve değişkenler arasında ileri sürülen ilişkilerin tespit edilmesi amacıyla çoklu regresyon analizi yapılmış ve analiz sonuçları Tablo 4' de belirtilmiştir.

Tablo 4. Regresyon Analizi Sonuçları

\begin{tabular}{|c|c|c|c|c|}
\hline \multirow{2}{*}{ Adımlar } & \multicolumn{3}{|c|}{ Regresyon Katsayıları } & \multirow{2}{*}{ Model İstatistikler } \\
\hline & Beta & St. Hata & $\beta$ & \\
\hline Birinci Adım & \multirow{3}{*}{-0.566} & \multirow{3}{*}{0.118} & \multirow{3}{*}{-1.221} & $\mathrm{R}^{2}=.321$ \\
\hline Bağımsız Değişken: Algılanan İş Güvencesizliği & & & & $F(1,425)=106.685$ \\
\hline Bağımlı Değişken: Yaşam Doyumu & & & & $\mathrm{p}<.01$ \\
\hline İkinci Adım & \multirow{3}{*}{0.600} & \multirow{3}{*}{0.021} & \multirow{3}{*}{0.242} & $\mathrm{R}^{2}=.360$ \\
\hline Bağımsız Değişken: Algılanan İş Güvencesizliği & & & & $F(1,425)=127.265$ \\
\hline Bağımlı Değişken: İşten Ayrılma Niyeti & & & & $\mathrm{p}<.01$ \\
\hline 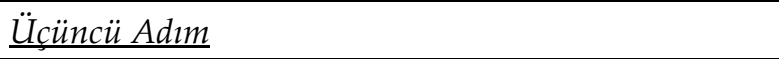 & \multirow{3}{*}{-0.272} & \multirow{3}{*}{0.243} & \multirow{3}{*}{-1.467} & $\mathrm{R}^{2}=.074$ \\
\hline Bağımsız Değişken: İşten Ayrılma Niyeti & & & & $F(1,425)=36.408$ \\
\hline Bağımlı Değişken: Yaşam Doyumu & & & & $\mathrm{p}<.01$ \\
\hline Dördüncü Adım & \multirow{2}{*}{-0.535} & \multirow{2}{*}{0.118} & \multirow{2}{*}{-1.153} & \\
\hline Bağımsız Değişken 1: Algılanan İş Güvencesizliği & & & & $\mathrm{R}^{2}=.351$ \\
\hline & \multirow{3}{*}{-0.177} & \multirow{3}{*}{0.294} & \multirow{3}{*}{-0.952} & $F(2,425)=60.830$ \\
\hline Bağımsız Değişken 2: İşten Ayrılma Niyeti & & & & $\mathrm{p}<.01$ \\
\hline Bağımlı Değişken: Yaşam Doyumu & & & & \\
\hline
\end{tabular}

Algılanan iş güvencesizliğiyle yaşam doyumu arasındaki ilişkide işten ayrılma niyetinin aracılık rolünü belirlemek için yapılan çoklu regresyon analizi sonuçlarına göre regresyon modeli istatistiksel bakımdan anlamlı olduğu görülmektedir ( $\mathrm{p}<0.05$ ). Baron ve Kenny (1986) tarafından önerilen aracıllk etkisi modeli kapsamında aracılık etkisini tespit edilebilmesi için ilk adımda algılanan iş güvencesizliğinin yaşam doyumu 
üzerindeki etkisi incelenmiştir. Açıklayıcı değişken olan algılanan iş güvencesizliğinin bağımlı değişken olan yaşam doyumu algısının varyansının \%32,1'ini açıkladığı görülmektedir $\left(\mathrm{R}^{2}=0.321 ; \mathrm{F}=106.685\right)$. İkinci adımda algılanan iş güvencesizliğinin aracı değişken olan işten ayrılma niyeti üzerindeki etkisi incelenmiş olup, algılanan iş güvencesizliğinin işten ayrılma niyetine yönelik varyansın \%30,6'sını açıkladığı görülmektedir $\left(R^{2}=0.360 ; F=127.265\right)$. Üçüncü adımda ise aracı değişken olan işten ayrılma niyetinin bağımlı değişken olan yaşam doyumu üzerindeki etkisi incelenmiş olup, işten ayrılma niyetinin yaşam doyumuna yönelik varyansın $\% 7,4^{\prime}$ ünü açıkladığı görülmektedir ( $\left.R^{2}=0.074 ; \mathrm{F}=36.408\right)$. Dördüncü adımda ise algılanan iş güvencesizliği ve işten ayrılma niyeti değişkenleri birlikte modele dahil edilerek bu değişkenlerin yaşam doyumu üzerindeki etkisi incelenmiş, algılanan iş güvencesizliği ve işten ayrılma niyetinin yaşam doyumu algısının varyansının $\% 35,1^{\prime}$ ini açıkladığ tespit edilmiştir $\left(R^{2}=0.351 ; F=60.830\right)$. Regresyon analizi sonucunda işten ayrılma niyeti değişkeni modele dahil edildiğinde algılanan iş güvencesizliğinin yaşam doyumu üzerindeki etkisi $\beta=-$ 0.566 'dan $\beta=-0,535$ 'e düşmektedir. Ayrıca işten ayrılma niyeti değişkeni modele dahil edildiğinde $\mathrm{R}^{2}=0.321^{\prime}$ den $\mathrm{R}^{2}=0.351^{\prime}$ e artış göstermekte ve regresyon modelinin açılayıcılı̆̆ı artmaktadır. İşten ayrılma niyeti değişkeninin modele dahil edildikten sonra iş güvencesizliği algısının etkisinin hem azalması hem de etkinin de anlamlı olması ( $\mathrm{p}<0.05)$, algılanan iş güvencesizliği ile yaşam doyumu arasındaki ilişkide işten ayrılma niyetinin kısmi aracılık rolüne sahip bir değişken olduğunu göstermektedir. Bulunan aracılık etkisinin anlamlılığını tespit etmeye yönelik olarak Sobel testi yapılmıştır. Sobel analizi sonucunda $z$ değeri 2,72 olarak hesaplanmış olup, z değeri istatistiksel bakımdan anlamlıdır $(\mathrm{p}<0.05)$.

Çoklu regresyon analizi sonuçlarına göre, en küçük VIF değerleri 1.033 olup, bu değer en üst sınır olarak kabul edilen $10^{\prime}$ dan düşüktür. Modelde en düşük tolerans değerinin ise 0.968 olduğu tespit edilmiştir. Tolerans değeri ise en alt sınır olan 0,10'dan yüksektir. Modelde en yüksek CI değeri 4.825 olarak hesaplanmış ve bu değer en üst sınır olan 30'dan oldukça düşüktür. Dolayısıyla modelde çoklu bağıntı problemine rastlanmamışır. Ayrıca modelde en yüksek Durbin-Watson katsayısı 2.171 olduğu gözlemlenmiş ve bu durumda otokorelasyon sorununun olmadığı tespit edilmiştir. Yapılan çoklu regresyon analizi sonuçları dikkate alındığında "Algılanan iş güvencesizliğini işten ayrılma niyetini pozitif yönde etkiler." şeklinde geliştirilen $\mathrm{H}_{1}$ hipotezi, "İşten ayrılma niyeti yaşam doyumunu negatif yönde etkiler" şeklinde geliştirilen $\mathrm{H}_{2}$ hipotezi, "Algılanan iş güvencesizliği yaşam doyumunu negatif yönde etkiler." şeklinde geliştirilen $\mathrm{H}_{3}$ hipotezi ile "Algılanan iş güvencesizliğinin yaşam doyumu üzerindeki etkisinde işten ayrılma niyetinin aracılık rolü vardır." şeklinde geliştirilen $\mathrm{H}_{4}$ hipotezinin desteklendiğini göstermektedir.

\section{SONUÇ VE TARTIŞMA}

Araştırmamızda, algılanan iş güvencesizliği, yaşam doyumuyla işten ayrılma niyeti arasındaki ilişkilerin incelenmesi amaçlanmaktadır. Örgütsel davranış yazınında algılanan iş güvencesizliğinin işten ayrılma niyetiyle pozitif yönde (Ashford vd., 1989; Ameen vd., 1995; Rosenblatt vd., 1999; Sverke vd., 2002; Chirumbolo ve Hellgren, 2003; Sora vd., 2010; Jiménez vd., 2017; Günalan, 2019), işten ayrılma niyetiyle yaşam doyumu arasında negatif yönde (Ghiselli vd., 2001; Rode vd., 2007; Pasupuleti vd., 2009: Y1lmaz vd., 2010; Lambert, 2010; Kışlalı, 2019:196; Yıldız ve Şimşek, 2020) ve algılanan iş güvencesizliğiyle yaşam doyumu arasında negatif yönde bir ilişkinin olduğu ifade edilmektedir (Sverke vd., 2002; De Witte, 2005; Berth, 2005; Silla vd., 2009; Green 2009). Bu doğrultuda çalışmanın bulguları mevcut literatürle benzerlik göstermektedir. Mevcut çalışmada elde edilen sonuçta, algılanan iş güvencesizliğinin işten ayrılma niyetini pozitif yönde etkilediği görülmektedir. Bu da iş güvencesizliği algısına sahip çalışanların işten ayrılma niyetlerinin yüksek olmasının nedenini göstermektedir. Yapılan araştırmalarda, iş güvensizliğinin bir sonucu olarak gönüllü işten ayrılma niyetine işaret etmekte ve tipik olarak işgücü piyasasında en çekici, en kalifiye aynı zamanda kuruluş için en değerli çalışanların işyerinden ayrılma eğiliminde ilk sırada olduğunu göstermektedir (Kozlowski vd., 1993; Pfeffer, 1998). Ayrıca, işten ayrılma niyeti ve algılanan iş güvencesizliğinin yaşam doyumunu negatif yönde etkilediği görülmektedir. Bunun yanı sıra algılanan iş güvencesizliğinin yaşam doyumu üzerindeki etkisinde işten ayrılma niyetinin aracılık rolü olduğu da tespit edilmiştir. Bu kapsamda psikolojik sözleşme teorisine dayanan iş güvencesizliğini algılayan çalışanların iş performanslarını olumsuz yönde etkileyeceğini bu durumunda çalışanların işten ayrılma niyetine yöneltecektir. İşten ayrılma niyetinde olan çalışanların da yaşam doyumuna olumsuz yönde etki edecektir. Ancak, algılanan iş güvencesizliğinin yaşam doyumu üzerindeki etkisinde işten ayrılma niyetinin aracılık rolünü araştıran çalışmalara rastlanılmamıştır. Bundan dolayı araştırma sonuçlarının özellikle aracılık ilişkisinin incelenmesi bakımından örgütsel davranış yazınına 
katkısı olacağı düşünülmektedir. Ancak, elde edilen bu bulguların genelleştirilebilirliğini incelemek için başka bağlamlarda ileride yapılacak çalışmalara ve farklı veri kaynaklarının kullanımına ihtiyaç söz konusudur.

Bu sonuçlar dikkate alındığında bu çalışma algılanan iş güvencesizliği, yaşam doyumu ve işten ayrılma niyeti değişkenlerini bir arada ele alması ve örgütsel davranış yazınında bu değişkenleri bir arada ele alan çalışmaya rastlanılmamış olması bakımından literatüre katkıda bulunmakta ve çalışmanın kalitesini göstermektedir. Gelecekte özellikle bu değişkenlerin farklı değişkenlerle ve özel sektör çalışanlarıyla araştırma konusu olarak ele alınması önerilmektedir. Mevcut araştırma, Konya ilindeki kamu çalışanlarıyla sınırlıdır. Farklı şehirlerde / örneklerde veya özel sektörde daha ileri çalışmalar yapılabilir. Ayrıca mevcut araştırma, araştırma soruları ve hipotezler niteliği alınarak belirli zaman sınırlamaları içinde yürütüldüğünden, veri toplama açısından daha uzun sürelerde ileri çalışmalar yapılabilmektedir. Çalışmada algılanan iş güvencesizliği kavramı çalışanların yaşam doyumu ve işten ayrılma niyetleri kapsamında değerlendirilmiştir. Bununla birlikte gelecekte yapılacak olan çalışmalarda çalışanların iş güvencesizliği algılamasına neden olabilecek iş tatmini, tükenmişlik, iş stresi, psikolojik sermaye, iyi oluş gibi çalışan tutumlarının yanı sıra örgütsel bağlılık, örgütsel sinizm, örgütsel güven gibi örgüte yönelik tutumların bir arada değerlendirilmesi önerilmektedir.

\section{KAYNAKÇA}

Ackerman, C. E. (2019). Life satisfaction theory and 4 contributing factors. Positive Psychology. https://positivepsychology.com/life-satisfaction/ (Erişim Tarihi: 21.02.2021).

Ameen, E. C., Jackson, C., \& Strawser, J. R. (1995). An empirical investigation of the antecedents and consequences of job insecurity on the turnover intentions of academic accountants, Issues in Accounting Education, 10, 65-83.

Appollis, V. P. (2010). The relationship between intention to quit, pyschological capital and job satisfaction in the tourism industry in the Western Cape (Doctoral dissertation, University of the Western Cape).

Ashford, S. J., Lee, C., \& Bobko, P. (1989). Content, cause, and consequences of job insecurity: A theory based measure and substantive test, Academy of Management Journal, 32, 803-829.

Baron, R. M., ve Kenny, D. A. (1986). The moderator-mediator variable distinction in social psychological research: Conceptual, strategic, and statistical considerations. Journal of Personality and Social Psychology, 51(6), 1173-1182.

Behery, M.; Abdallah, S.; Parakandi, M., \& Kukunuru, S. (2016). Psychological Contracts and Intention to Leave with Mediation Effect of Organizational Commitment and Employee Satisfaction at Times of Recession, Review of International Business and Strategy, 26(2), 184-203.

Berth, H., Förster, P., \& Brähler, E. (2005). Arbeitslosigkeit, Arbeitsplatzunsicherheit und Lebenszufriedenheit: Ergebnisse einer Studie bei jungen Erwachsenen in den neuen Bundesländern, Sozial-und Präventivmedizin, 50(6), 361-369.

Boshoff, A.B., Van Wyk, R., Hoole, C., \& Owen, J.H. (2002). The prediction of intention to quit by means of biographic variables, work commitment, role strain and psychological climate, Management Dynamics, $11(4), 14-28$.

Buitendach, J. H. \& De Witte, H. (2005). Job insecurity, extrinsic and intrinsic job satisfaction and affective organisational commitment of maintenance workers in a parastatal, South African Journal of Business Management, 36(2), 27-37.

Burgard, S. A., Brand, J. E., \& House, J. S. (2009). Perceived job insecurity and worker health in the United States, Social Science \& Medicine, 69(5), 777-785. Doi: 10.1016/j.socscimed.2009.06.029

Chirumbolo, Antonio; Hellgren, Johnny. 2003. “Individual and organizational consequencesof job insecurity: A European study", in Economic and Industrial Democracy, 24 (2), 217-240.

Cho, S., Johanson, M. M., \& Guchait, P. (2009). Employees intent to leave: A comparison of determinants of intent to leave versus intent to stay, International Journal of Hospitality Management, 28(3), 374-381.

Clark, L. J. (2005). Moderators of the effects of perceived job insecurity: A comparison of temporary and permanent employees (Doctoral dissertation, Queensland University of Technology). 
Costa, S., \& Neves, P. (2017). Job insecurity and work outcomes: The role of psychological contract breach and positive psychological capital, Work \& Stress, 31(4), 375-394.

Coşkun, R., Altunışık, R., Bayraktaroğlu, S., \& Yıldırım, E. (2015). Sosyal Bilimlerde Araştırma Yöntemleri, Sakarya: Sakarya Yayıncilık.

Davy, J. A., Kinicki, A. J., \& Scheck, C. L. (1997). A test of job security's direct and mediated effects on withdrawal cognitions, Journal of Organizational Behavior: The International Journal of Industrial, Occupational and Organizational Psychology and Behavior, 18(4), 323-349.

De Cuyper, N., De Witte, H., Vander Elst, T., \& Handaja, Y. (2010). Objective threat of unemployment and situational uncertainty during a restructuring: Associations with perceived job insecurity and strain, Journal of Business and Psychology, 25(1), 75-85.

De Witte, H. (2005). Job insecurity: Review of the international literature on definitions, prevalence, antecedents and consequences, SA Journal of Industrial Psychology, 31(4), 1-6.

De Witte, H. (1999). Job insecurity and psychological well-being: review of the literature and exploration of some unresolved issues, European Journal of Work and Organizational Psychology, 8(2), 155-177.

Demerouti, E., Bakker, A. B., Nachreiner, F., \& Schaufeli, W. B. (2000). A model of burnout and life satisfaction amongst nurses, Journal of Advanced Nursing, 32(2), 454-464.

Diener, E. D., Emmons, R. A., Larsen, R. J., \& Griffin, S. (1985). The satisfaction with life scale, Journal of Personality Assessment, 49(1), 71-75.

Emberland, J. S., \& Rundmo, T. (2010). Implications of job insecurity perceptions and job insecurity responses for psychological well-being, turnover intentions and reported risk behavior, Safety Science, 48(4), 452459. Doi: 10.1016/j.ssci.2009.12.002.

Ghiselli, R. F., La Lopa, J. M., \& Bai, B. (2001). Job satisfaction, life satisfaction, and turnover intent: Among food-service managers, Cornell Hotel and Restaurant Administration Quarterly, 42(2), 28-37.

Goldbeck, L., Schmitz, T. G., Besier, T., Herschbach, P., \& Henrich, G. (2007). Life satisfaction decreases during adolescence, Quality of Life Research, 16(6), 969-979.

Green Francis, (2009). Job insecurity, employability, unemployment and well-being, School of Economics Discussion Papers, 09,18, 18, University of Kent, School of Economics, Canterbury.

Greenhalgh, L., \& Rosenblatt, Z. (1984). Job insecurity: toward conceptual clarity, The Academy of Management Review, 9, 438-448. http://dx.doi.org/10.2307/258284.

Günalan, M. (2019). İş güvencesizliğinin örgütsel algılar, ayrılama niyeti ve performansa etkileri üzerine bir literatür incelemesi, International Review Of Economics And Management, 7(2), 105-122.

Gürbüz, F. G., \& Dede, Ezgi (2018). The relationship between perceived job insecurity and organizational citizenship behaviors of middle school teachers, Eğitim Bilimleri Araştırmaları Dergisi, 8(1), 73-88.

Ngo, H.-Y., Loi, R., \& Foley, S. (2013). Perceived job insecurity, psychological capital and job attitudes: An investigation in Hong Kong, International Journal of Employment Studies, 21(1), 58.

Hassard, J., Teoh, K. And Cox, T., (2013). Job insecurity. Bilbao, Spain: EU-OSHA (European Agency for Safety \& Health at Work).

Heaney, C. A., Israel, B. A., \& House, J. S. (1994). Chronic job insecurity among automobile workers: Effects on job satisfaction and health, Social Science \& Medicine, 38(10), 1431-1437.

Ismail, H. (2015). Job insecurity, burnout and intention to quit, International Journal of Academic Research in Business and Social Sciences, 5(4).

Jiménez, P., Milfelner, B., Šarotar Žižek, S., \& Dunkl, A. (2017). Moderating Effects between Job Insecurity and Intention to Quit in Samples of Slovene and Austrian Workers, Naše gospodarstvo/Our Economy, 63(1), 27-37. Doi: 10.1515/ngoe-2017-0003.

Kasprzak, E. (2010). Perceived social support and life-satisfaction, Polish Psychological Bulletin, 41(4), 144-154.

Kekesi, E. K., \& Agyemang, C. B. (2014). Perceived job insecurity and psychological distress: The moderating role of work values, International Journal of Management, Economics and Social Sciences, 3(1), 18-35.

Kışlalı, İ. (2019). “Koçluk Hizmeti Alan Çalışanların Mutluluk Düzeyleriyle İşten Ayrılma Niyeti ve Yaşam Doyumu Arasındaki İlişki". Uluslararası Yönetim İktisat ve İşletme Dergisi, 15 (1), 181-202. 
Kozlowski, S., Chao, G., Smith, E., \& Hedlund, J. (1993). Organizational downsizing: Strategies, interventions and research implications. In C. L. Cooper \& I. T. Robertson (Eds.), International review of industrial and organizational psychology $(8,263-332)$. New York: Wiley.

Köker, S. (1991). Normal ve sorunlu ergenlerin yaşam doyumu düzeyinin karşılaştırılması (Yüksek Lisans tezi). Ankara Üniversitesi Sosyal Bilimler Enstitüsü, Ankara.

Lam, K. K. L., \& Zhou, M. (2020). A serial mediation model testing growth mindset, life satisfaction, and perceived distress as predictors of perseverance of effort, Personality and Individual Differences, 167, 110262. Doi: 10.1016/j.paid.2020.110262.

Lambert, E. G., Hogan, N. L., \& Altheimer, I. (2010). An exploratory examination of the consequences of burnout in terms of life satisfaction, turnover intent, and absenteeism among private correctional staff, The Prison Journal, 90(1), 94-114.

Landsbergis, P. A., Grzywacz, J. G., \& LaMontagne, A. D. (2014). Work organization, job insecurity, and occupational health disparities, American Journal of Industrial Medicine, 57(5), 495-515.

Lim, V. (1997). Moderating effects of work-based support on the relationship between job insecurity and its consequences, Work \& Stress, 11 (3), 251-266.

Mathebula, L., Mulenga M., Clinton A. and Wellington D. T. (2015). 'A Theoretical Assessment of Causes of Job Insecurity in the Construction Industry.' Proceeding of the 12th International OTMC ConferenceOrganisation, Technology, and Management in Construction, 2-6 September 2015, Primošten, Croatia. Primošten: 1-6.

Mobley, W. H. (1977). Intermediate linkages in the relationship between job satisfaction and employee turnover, Journal of Applied Psychology, 62(2), 237-240.

Mobley, W.H., Horner, S.O., \& Hollingsworth, A.T. (1978). An evaluation of precursors of hospital employee turnover, Journal of Applied Psychology, 63 (4), 408 - 414.

Muchinsky, P.M., \& Morrow, P.C. (1980). A multidisciplinary model of voluntary employee turnover, Journal of Vocational Behaviour, 17, $263-290$.

Nella, D., Panagopoulou, E., Galanis, N., Montgomery, A., \& Benos, A. (2015). Consequences of Job Insecurity on the Psychological and Physical Health of Greek Civil Servants, BioMed Research International, 2015, 1-8. doi:10.1155/2015/673623

Pasupuleti, Sudershan; Reva I. Allen, Eric G. Lambert \& Terry Cluse-Tolar (2009). The Impact of Work Stressors on the Life Satisfaction of Social Service Workers: A Preliminary Study, Administration in Social Work, 33:3, 319-339, DOI:10.1080/03643100902988141.

Perrone, K. M., \& Civiletto, C. L. (2004). The impact of life role salience on life satisfaction, Journal of Employment Counseling, 41(3), 105-116.

Pfeffer, J. (1998). The Human Equation: Building Profits by Putting People First. Boston: Harvard University Press.

Price, J.L. (1989). The impact of turnover on the organisation, Work and Occupations, 16 (4), $461-473$.

Rizwan, M., Arshad, M. Q., Munir, H. M. A., Iqbal, F., \& Hussain, A. (2014). Determinants of Employees intention to leave: A Study from Pakistan, International Journal of Human Resource Studies, 4(3), 1-18.

Rode, J. C., Rehg, M. T., Near, J. P., \& Underhill, J. R. (2007). The effect of work/family conflict on intention to quit: The mediating roles of job and life satisfaction, Applied Research in Quality of Life, 2(2), 65-82.

Rosenblatt, Zehava; Talmud, Ilan; Ruvio, Ayalla. (1999). “A gender-based framework of theexperience of job insecurity and its effects on work attitudes", European Journal of Work and Organizational Psychology, 8(2), 197-217.

Salas-Nicás, S., Moncada, S., Llorens, C., Moriña, D., \& Navarro, A. (2020). A complex view of perceived job insecurity: Relationship between three domains and their respective cognitive and affective components, Safety Science, 129, 104796.

Seçer, B. (2011). İş güvencesizliğinin içsel işten ayrılma ve yaşam doyumuna etkisi, İş, Güç: The Journal of Industrial Relations \& Human Resources, 13(4).

Silla, I., De Cuyper N., Gracia F. J., Peiro' Jose' M., De Witte Hans, (2009). Job Insecurity and Well- Being: Moderation by Employability, Journal of Happiness Studies, 10. 
Skelton, A. R., Nattress, D., \& Dwyer, R. J. (2019). Predicting manufacturing employee turnover intentions, Journal of Economics, Finance and Administrative Science. Doi:10.1108/jefas-07-2018-0069

Sora, B., Caballer, A., \& Peiró, J. M. (2010). The consequences of job insecurity for employees: The moderator role of job dependence, International Labour Review, 149(1), 59-72.

Sousa, L., \& Lyubomirsky, S. (2001). Life satisfaction. In J. Worell (Ed.), Encylopedia of women and gender: Sex similarities and differences and the impact of society on gender (2, 667-676). San Diego, CA:Academic Press.

Sverke, M., Hellgren, J., \& Näswall, K. (2002). No security: a meta-analysis and review of job insecurity and its consequences, Journal of Occupational Health Psychology, 7(3), 242.

Tivendell, J. ve Bourbonnais, C. (2000). Job Insecurity in a Sample of Canadian Civil Servants as a Function of Personality and Perceived Job Characteristics, Psychological Reports, 87(1), 55-60.

Van Schalkwyk, S., Du Toit, D.H., Bothma, A.S., \& Rothmann, S. (2010). Job insecurity, leadership empowerment behaviour, employee engagement and intention to leave in a petrochemical laboratory. SA Journal of Human Resource Management, 8(1), 7, DOI: 10.4102/sajhrm. v8i1.234.

Van Vuuren, C. V., \& Klandermans, P. G. (1990). Individual Reactions to Job Insecurity: An Integrated Model. In P. J. D. Drenth, J. A. Sergeant, \& R. J. Takens (Eds.), European perspectives in psychology, 3. Work and organizational, social and economic, cross-cultural (133-146). John Wiley \& Sons.

Van Vuuren, T. (1990). Met ontslag bedreigd. Werknemers in onzekerheid over hun arbeidsplaats bij veranderingen in de organisatie. Amsterdam: VU Uitgeverij.

Vandenberg, R.J., \& Nelson, J.B. (1999). Disaggregating the motives underlying turnover intentions: When do intentions predict turnover behaviour? Human Relations, 52, 1313 - 1336.

Veenhoven, R. (1996). The study of life-satisfaction. Saris, W.E., Veenhoven, R., Scherpenzeel, A.C. \& Bunting B. (eds) 'A comparative study of satisfaction with life in Europe. Eötvös University Press, 1996, ISBN963 $4630812,11-48$

Yıldız, T., \& Şimşek, Y. (2010). Sivil havacılık işletmelerinde çalışanların yaşam doyumunun, iş stresi ve işten ayrılma niyetine etkisinin belirlenmesi: Kars Harakani hava limanı örneği, Çalışma İlişkileri Dergisi, 11(2), 59-76.

Yılmaz, Y., Keser, D. ve Yorgun, Y. (2020). “Konaklama işletmelerinde çalışan sendika üyelerinin iş ve yaşam doyumunu belirlemeye yönelik bir alan araştırması", Paradoks Ekonomi Sosyoloji ve Politika Dergisi, 6 (1), 87-107.

Zhang, X., \& Zhou, S. (2012). Job insecurity, psychological capital, and employee creativity-The moderating role of organizational innovation climate. 2012 International Symposium on Management of Technology (ISMOT). Doi:10.1109/ismot.2012.6679460.

Zhen, Y., \& Mansor, Z. D. (2019). A review on the relationship between psychological capital and job attitudes with the mediatıng effect of work engagement in hotel industry, Journal Of Critical Reviews, 7(2), 2020. 